\title{
DOKTER BUMIPUTERA LULUSAN STOVIA DAN KONTRIBUSINYA DALAM PENANGANAN WABAH FLU SPANYOL DI HINDIA BELANDA (1918-1920)
}

\author{
Saifuddin Alif Nurdianto \\ SMAN 1 Sambit \\ Jalan Raya Ponorogo-Trenggalek, Sambit, Ponorogo. \\ email: saifuddinalif2@gmail.com
}

\begin{abstract}
Abstrak
STOVIA didirikan oleh pemerintah Hindia Belanda pada 1849, yang ketika itu bernama Dokter Djawa School. Semasa STOVIA masih eksis ada satu peristiwa yang cukup menyita perhatian karena besarnya dampak yang ditimbulkan. Peristiwa itu adalah penyebaran wabah flu Spanyol yang menyebabkan 1,5 juta sampai 4,37 juta rakyat Hindia-Belanda meninggal. Pada periode tersebut peran dan kontribusi dari para tenaga medis dibutuhkan oleh segenap rakyat. Para dokter pribumi alumni STOVIA menjadi orang yang merasa paling memiliki tanggung jawab untuk ikut serta menangani pandemi. Penelitian historis dengan pendekatan sosiologis akan digunakan untuk mengkaji kontribusi para dokter pribumi alumni STOVIA dalam penanganan pandemi flu Spanyol di Hindia Belanda. Hasil penelitian menunjukkan bahwa kontribusi para dokter ini tidak terbatas dalam bidang medis, tetapi juga dalam bidang sosial, akademik, dan politik.
\end{abstract}

Kata kunci: STOVIA, wabah, flu Spanyol, Hindia Belanda.

\section{THE CONTRIBUTION OF NATIVE INDIES PHYSICIAN GRADUATES OF STOVIA WHEN THE SPANISH FLU PLAGUE HIT DUTCH EAST INDIES (1918-1920)}

\begin{abstract}
STOVIA was founded by the Dutch East Indies government in 1849, which was then named Dokter Djawa School. When STOVIA still existed a pandemic case that attracted enough attention for its big impact happened. The case was the spread of the Spanish flu plague which killed 1.5 million to 4.37 million people. The native doctors who graduated from STOVIA became the people who took the responsibility in dealing with the pandemic. Historical research with a sociological approach was conducted to examine the contribution of the native doctors who graduated from STOVIA in handling the Spanish flu pandemic. The results showed that the contributions of these doctors were not limited to the medical field, but also in the social, academic and politic.
\end{abstract}

Keywords: STOVIA, plague, Spanish flu, Dutch East Indies

\section{PENDAHULUAN}

2020-2021 menjadi tahun yang kurang baik bagi masyarakat dunia karena pandemi Covid-19. Covid-19 adalah penyakit yang disebabkan oleh virus severe acute respiratory syndrome coronavirus 2 (SARS-CoV-2) yang juga sering disebut dengan virus korona. Virus

Naskah masuk: 07 - 01 - 2021 ; Revisi akhir: 24 - 02 - 2021 ; Disetujui terbit: 28 - 03 - 2021 
ini pertama kali muncul di Wuhan tahun 2019, sebelum akhirnya menyebar ke seluruh dunia. Data dari World Health Organization (WHO) menunjukkan bahwa per Maret 2021 jumlah kasus positif Covid-19 di seluruh dunia adalah 124.871.140 dengan korban meninggal 2.744.543. Di Indonesia, per Maret 2021 jumlah kasus positif Covid-19 adalah 1.482.559 dengan korban meninggal 40.081 (www.covid19.who.int, 2021).

Pandemi Covid-19 bukanlah pandemi pertama yang dialami oleh umat manusia. Pandemi selalu terjadi dalam kurun waktu tertentu, baik dalam skala regional maupun global. Dalam dunia modern tercatat ada sembilan pandemi yang pernah melanda dunia yaitu, kolera (1852-1860), flu Rusia (1889-1890), kolera (1899-1923), flu Spanyol (1918-1919), flu Asia (1956-1958), flu Hong Kong (1968-1969), SARS (2002-2003), dan MERS (2012-sekarang) (Jocelyne Piret \& Boivin, 2021). Dari sekian pandemi, flu Spanyol menjadi salah satu yang menarik untuk dikaji karena banyaknya jumlah korban besarnya dampak yang ditimbulkan. Hampir 3 miliar penduduk dunia saat itu terkena dampak dari pandemi flu Spanyol, baik terjangkit langsung, meninggal dunia, atau terkena dampak sosial dan ekonomi akibat pandemi (Wibowo, 2009: 28).

Mayoritas peneliti percaya bahwa influenza 1918 berasal dari Amerika kemudian menyebar ke Eropa sebelum kemudian menyebar ke seluruh dunia. Istilah flu Spanyol muncul karena Spanyol adalah negara yang pertama kali memberitakan tentang wabah influenza ini. Indonesia yang pada tahun 1918 masih di bawah kekuasaan pemerintah kolonial HindiaBelanda juga tidak terhindar dari flu Spanyol. Penyakit ini masuk ke Hindia-Belanda melalui penumpang-penumpang kapal asal Hongkong yang melakukan hubungan dagang dengan Batavia, setelah sebelumnya singgah di Singapura. Menurut Boomgard, banyaknya kapal Hongkong yang datang ke Batavia adalah akibat dari semakin membaiknya transportasi laut pada abad ke-20 dan meningkatnya aktivitas dagang antara Belanda dengan Inggris sebagai penguasa Hongkong pada kurun waktu tersebut (Boomgaard, 1993: 79). Tingginya interaksi antara Hongkong dengan Batavia ternyata kurang diperhatikan oleh pemerintah kolonial Belanda. Kabar tentang penyebaran virus H1N1 di Hongkong tidak diantisipasi dengan tindakan pencegahan yang serius. Sikap pemerintah kolonial ini yang kemudian menjadi awal dari penyebaran virus influenza di seluruh kawasan Hindia-Belanda (Wibowo, 2009: 93-95).

Indonesia yang pada tahun 1918 masih menjadi jajahan Belanda menjadi salah satu wilayah dengan kasus flu Spanyol terparah di dunia. Dalam penelitiannya, Brown memperkirakan lebih dari 1,5 juta rakyat Hindia-Belanda tewas akibat pandemi (Brown, 1987: 235). Sementara itu, catatan dari Ravando menunjukkan bahwa rata-rata kematian (death rate) yang ada di Hindia Belanda akibat pandemi flu Spanyol adalah 30,4 per 1000 orang. Ravando memperkirakan 1,5 juta sampai 4,37 juta rakyat Hindia Belanda meninggal akibat pandemi flu Spanyol (Ravando, 2020) Angka-angka hasil penelitian ini memang masih belum pasti karena keterbatasan data. Selain itu, kondisi dunia yang masih disibukkan dengan Perang Dunia I juga menjadi alasan. 
Pandemi flu Spanyol, sebagaimana pandemi-pandemi lain di seluruh dunia, menjadikan tenaga medis sebagai tumpuan utama untuk mengatasinya. Di Hindia Belanda yang dijadikan tumpuan untuk mengatasi pandemi, selain sedikit dari tenaga medis Belanda, adalah para lulusan dari sekolah kedokteran yang ada pada saat itu, yaitu School tot Opleiding van Indische Artsen (STOVIA) dan Nederlandsch Indische Artsen School (NIAS). Dengan mempertimbangkan lulusan kedua sekolah ini dari tahun 1890-1918 ditambah tenaga kesehatan dari golongan Eropa, ada sekitar 3000-5000 tenaga kesehatan yang ada di Hindia Belanda. Jumlah dokter tentu tidak sebanding dengan jumlah populasi yang ada pada kisaran 48 juta jiwa, atau 0,006\%-0,01\% dari jumlah populasi. Angka ini memang baru sebatas perkiraan. Angka pastinya tidak dapat diketahui karena sensus penduduk baru dilakukan pertama kali tahun 1920 dengan total populasi 49,3 juta jiwa.

Di tengah keterbatasan jumlah tenaga kesehatan, para alumni STOVIA berusaha untuk mengabdi kepada masyarakat dengan mengamalkan ilmu-ilmu yang telah didapat semasa sekolah guna meredakan pandemi flu Spanyol yang sedang melanda Hindia Belanda. Pengabdian yang dilakukan meliputi bidang kesehatan, sosial, dan politik. Dalam bidang kesehatan dilakukan dengan mengobati para pasien dan melakukan penelitian yang relevan terkait penyakit flu Spanyol, dalam bidang sosial dilakukan dengan sosialisasi kepada masyarakat, dan dalam bidang politik dilakukan dengan memperjuangkan aspirasi rakyat Hindia melalui Dewan Rakyat atau Volksraad.

Tulisan tentang aktivitas dan peran para dokter lulusan STOVIA memang bukan pertama ini dilakukan. Beberapa tulisan yang dapat dijadikan rujukan antara lain Nurturing Indonesia: Medicine and Decolonisation in the Dutch East Indies karya Hans Pols, Healers on the Colonial Market karya Liesbeth Hesselink, dan Epidemi Penyakit Pes di Malang, 1911-1916 karya Syefri Luwis. Keterbaruan dari tulisan ini terletak pada obyek kajiannya, yaitu secara lebih spesifik menjelaskan tentang peran para dokter alumni STOVIA dalam penanganan wabah flu Spanyol di Hindia Belanda.

Metode penelitian historis dengan pendekatan sosiologis akan digunakan dalam penelitian ini. Tema tentang peran dokter alumni STOVIA dalam penanganan pandemi 1918 menarik untuk dikaji karena flu Spanyol merupakan salah satu wabah yang paling banyak menewaskan umat manusia. Selain itu, pandemi flu Spanyol yang melanda Hindia Belanda pada akhir kuartal pertama abad 20 menjadi salah satu ujian atas nasionalisme para dokter pribumi dan tantangan untuk mengaplikasikan ilmu-ilmu yang telah didapat. Lebih lanjut kajian ini juga akan mengungkap pentingnya peran para dokter pribumi, di tengah keterbatasan informasi informasi dan ilmu pengetahuan yang dimiliki oleh rakyat jajahan.

\section{PEMBAHASAN}

\section{A. Sejarah Pendirian STOVIA}

STOVIA adalah kependekan dari School tot Opleiding van Indische Artsen atau Sekolah Pelatihan Dokter Hindia. Sekolah ini didirikan di Woltevreden, Batavia, pada 1849 atas 
usulan dari Willem Bosch (1798-1874), seorang dokter berkebangsaaan Belanda yang pada tahun tersebut menjabat sebagai Kepala Dinas Kesehatan (Chef van de Geneeskundige Dienst) di Batavia. Ada tiga alasan kenapa Bosch mengusulkan kepada pemerintah kolonial Hindia Belanda untuk mendirikan sekolah kedokteran: (1) untuk memenuhi kebutuhan tenaga kesehatan di perkebunan gula dan tembakau milik Belanda di Jawa dan Sumatera, (2) kurangnya tenaga kesehatan ketika terjadi wabah cacar yang disertai demam tinggi di Jawa Tengah pada tahun 1846-1847, dan (3) mendidik pemuda-pemuda Jawa yang memiliki bakat di bidang kedokteran dan bersedia menjadi dokter-dokter praktik (praktische geneesheren) di rumah sakit-rumah sakit militer Belanda di Jawa (Zwierstra, 2009: 82).

Faktor kedua, cacar disertai demam tinggi, adalah alasan spesifik kenapa pendirian sekolah kedokteran di Hindia-Belanda bersifat mendesak. Banyumas adalah kabupaten yang rakyatnya paling banyak meninggal akibat wabah tersebut. Pemerintah kolonial menindaklanjuti informasi kematian rakyat Banyumas akibat wabah cacar dengan memberikan instruksi kepada Bosch untuk membagikan pedoman singkat mengenai cara mempertahankan kesehatan dan cara menggunakan obat-obatan tradisional dengan harga terjangkau kepada para kepala desa di Banyumas. Instruksi ditindaklanjuti oleh Bosch, sekaligus dijadikan momentum untuk mengusulkan pembentukan suatu korps dokter, yang berasal dari penduduk pribumi dan dapat digunakan untuk memenuhi kebutuhan tenaga kesehatan (Radiopoetro, 1976: 141).

Usulan Bosch tentang usulan pembentukan korps dokter oleh pemerintah kolonial Hindia-Belanda disetujui dengan dikeluarkannya keputusan pemerintah (gouvernementsbesluit) no. 22 tanggal 2 Januari 1849 tentang pembentukan Sekolah Dokter Jawa (Dokter Djawa School). Meskipun surat keputusan dikeluarkan tahun 1849, tetapi tindak lanjut dari keputusan tersebut baru dilaksanakan pada Januari 1851. Pieter Bleeker ditunjuk sebagai direktur Sekolah Dokter Djawa yang pertama (Bleeker, 1877: 21). Syarat masuk Sekolah Dokter Djawa ada dua, yaitu berasal dari keluarga yang baik dan mampu melakukan kegiatan baca tulis dalam bahasa Jawa dan Melayu (Radiopoetro, 1976). Kemampuan baca tulis dalam bahasa Jawa dan Melayu inilah poin yang cukup sulit untuk dipenuhi rakyat pada periode tersebut.

Siswa yang pertama diterima hanya berjumlah dua belas orang yang disebut dengan eleves. Lama pendidikan yang harus ditempuh oleh para siswa adalah dua tahun (Hesselink, 2011: 84). Tahun 1853 Dokter Djawa School meluluskan 11 siswa dengan gelar yang masih belum jelas. Dikatakan belum jelas karena terjadi perdebatan tentang gelar yang akan disandang oleh 11 lulusan ini. Bosch ingin agar 11 alumni pertama Dokter Djawa School menyandang gelar dokter. Keinginan ini ditolak oleh Dewan Hindia (Raad van Indie) yang menganggap gelar dokter terlalu istimewa untuk orang pribumi. Dewan Hindia menginginkan lulusan Dokter Djawa School cukup sebagai vaccinateur atau juru cacar. Perdebatan diakhiri dengan keputusan yang dikeluarkan oleh pemerintah bulan Juni 1853 bahwa alumni Dokter Djawa School berhak menyandang gelar "Dokter Djawa" setelah mengikuti kursus tingkat lanjut (Hesselink, 2011: 84). 
Perubahan nama dari Dokter Djawa School menjadi School tot Opleiding van Inlandsche Artsen (STOVIA) terjadi pada tahun 1902, yang alumninya disebut dengan Inlandsch art atau dokter pribumi. Lulusan STOVIA adalah siswa yang telah mengikuti kelas persiapan selama tiga tahun dan kelas kedokteran selama enam tahun atau total sembilan tahun. Penambahan ini terkait dengan penambahan mata kuliah yaitu obstetri dan forensik (Neelakantan, 2013).

Sedikit perubahan terjadi pada tahun 1913 dimana kata Inlandsche diubah menjadi Indisch, sehingga lulusan STOVIA berhak menyandang gelar Indisch art atau dokter Hindia. Lama pendidikan kedokteran diubah menjadi tujuh tahun. Jadi sejak tahun 1913 seorang siswa harus menyelesaikan pendidikan selama sepuluh tahun di STOVIA jika ingin menjadi seorang dokter (Hesselink, 2011: 163).

Meskipun awal didirikannya STOVIA ditujukan untuk mendidik calon dokter beretnis Jawa, tetapi dalam perkembangannya STOVIA juga menerima siswa dari latar belakang etnis yang beragam. Selain keragaman etnis, keragaman latar belakang sosial juga dimiliki oleh siswa-siswa STOVIA. Menariknya, karena STOVIA dirancang sebagai sekolah yang tidak berbayar, pada periode awal mayoritas siswa STOVIA adalah rakyat miskin yang tidak memiliki biaya untuk sekolah. Jumlah ini kemudian menurun seiring semakin dihargainya profesi tenaga medis di Hindia-Belanda. Data dari Hesselink menunjukkan bahwa pada tahun 1895-1904, jumlah siswa yang berlatar belakang priyayi sebanyak 90 (27\%), golongan menengah 159 (48\%), dan golongan bawah 83 (25\%) (Hesselink, 2011: 206).

Perkiraan jumlah alumni STOVIA sampai tahun 1918, tahun ketika terjadi pandemi flu Spanyol, adalah 1500 orang. Jumlah ini didapat dengan mempertimbangkan siswa yang tidak dapat menyelesaikan pendidikan kedokteran selama belajar di STOVIA. Dari sekian alumni, hampir $90 \%$ bekerja di fasilitas kesehatan milik pemerintah kolonial, baik yang berskala kecil maupun besar.

Dalam perjalanannya, para alumni STOVIA ternyata tidak hanya bergerak dalam bidang kesehatan, tetapi juga sosial dan politik. Alumni-alumni STOVIA tergerak untuk memperbaiki nasib rakyat Hindia yang masih terbelenggu penjajahan Belanda. Tiga contoh yang dapat disebutkan adalah Cipto Mangunkusumo yang ikut bergerak dalam bidang politik dengan mendirikan Indische Partij, Soetomo dan Wahidin Soedirohoesodo yang bergerak dalam bidang sosial kebudayaan dengan mendirikan organisasi Boedi Oetomo, dan Abdul Rivai yang aktif dalam bidang jurnalistik dengan memprakarsai berdirinya surat kabar Pewarta Wolanda tahun 1900 dan dalam bidang politik dengan menjadi anggota Volksraad tahun 1918 (Poeze, 1989: 88).

\section{B. Wabah Influenza Spanyol di Hindia Belanda}

Flu Spanyol berasal dari virus influenza tipe A subtipe H1N1. Mayoritas peneliti percaya bahwa influenza 1918 berasal dari Amerika kemudian menyebar ke Eropa sebelum kemudian menyebar ke seluruh dunia. Istilah flu Spanyol muncul karena Spanyol adalah negara yang pertama kali memberitakan tentang wabah influenza ini. Negara-negara besar Eropa dan Amerika enggan memberitakan karena sedang disibukkan dengan Perang Dunia I 
(Salvadó, 2019: 46). Segera setelah itu istilah flu Spanyol menjadi populer digunakan untuk menyebut penyakit influenza yang sedang merebak tersebut (Taubenberger, 2006).

Flu Spanyol masuk ke Hindia ........Belanda melalui interaksi dagang dengan pelautpelaut dari Hongkong pada awal tahun 1918. Pada tahun itu informasi tentang penyebaran virus H1N1-1918 bukannya tidak ada. Pemerintah Inggris di Singapura telah mengeluarkan larangan bagi kapal-kapal dari Hongkong untuk menurunkan penumpang, kecuali bagi yang sudah diperiksa oleh tim medis. Pemerintah Hindia-Belanda di Batavia juga sudah mendengar tentang berita ini. Sayangnya pemerintah kolonial tidak melihat flu Spanyol sebagai suatu penyakit yang berbahaya. Pemerintah Hindia-Belanda di Batavia bereaksi hanya dengan melakukan tindakan preventif, yaitu memperketat pengawasan terhadap kapalkapal dari Hongkong, tanpa adanya penerapan protokol kesehatan yang ketat (Mansyur, 2020: 11).

Akibatnya, bulan Juli 1918 sudah ada laporan dari rumah sakit Hindia-Belanda tentang kedatangan pasien yang terkena penyakit influenza. Jumlah pasien semakin meningkat pada bulan Agustus dan September. Meningkatnya jumlah pasien influenza dalam kurun waktu dua bulan ternyata masih belum ditanggapi secara serius oleh pemerintah kolonial HindiaBelanda. Pemerintah berdalih bahwa rasio perbandingan jumlah pasien influenza dengan jumlah penduduk dianggap masih rendah (Wibowo, 2009: 95).

Pemerintah kolonial mulai memperhatikan secara serius penyebaran virus H1N1-1918 setelah adanya laporan tentang kenaikan jumlah pasien influenza dari berbagai daerah seperti Banjarmasin, Buleleng, Mojowarno, dan Banyuwangi. Laporan dari surat kabar Sin Po bertanggal 28 Oktober 1918 juga menyebutkan bahwa penyakit ini memiliki tingkat penularan yang cepat, sehingga menjangkiti rakyat di seantero negeri (Hindia-Belanda) (NN, 1918). Meskipun sedikit berlebihan, dari reportase Sin Po dapat diketahui bahwa flu Spanyol memang memiliki tingkat penularan yang tinggi. Tingginya tingkat penularan penyakit ini diperparah dengan kualitas penanganan yang buruk dari pemerintah kolonial. Akibatnya, di pulau Jawa dan Madura saja, penyakit flu Spanyol menewaskan lebih dari 2,5 juta jiwa (Chandra, 2013: 191).

Buruknya kualitas penanganan pandemi 1918 oleh pemerintah kolonial ditunjukkan dengan lambatnya kebijakan dan langkah-langkah yang diambil. Lambatnya langkah pemerintah terjadi karena tidak adanya master plan penanganan pandemi. Lembaga partikelir seperti Nederlandsch Zending Genootschap bahkan membuat inisiatif sendiri dengan melakukan sosialisasi terhadap masyarakat tentang gejala flu Spanyol, edukasi tentang cara menyikapinya, dan kurasi terhadap pasien-pasien yang sudah dirawat di rumah sakit (Wibowo, 2009: 100).

Langkah awal yang dilakukan oleh pemerintah kolonial adalah dengan membentuk tim di bawah Burgerlijken Geneeskundigen Dienst (BGD) atau Dinas Kesehatan Rakyat untuk menyelidiki tentang penyakit influenza yang sedang menyebar dan rekomendasi tentang tindakan yang harus dilakukan. Tim ini terdiri dari CD de Langen (ketua), GOE Lignac (sekretaris), PC Flu, AA Hulshoff, J Huizinga, dan Mas Sardjito (anggota). Hasil penelitian kemudian disosialisasikan melalui jalur birokrasi dari tingkat pusat sampai ke tingkat paling 
bawah yaitu desa. Selain itu Departement van Onderwijs en Eeredienst atau Departemen Pendidikan dan Agama diberikan tanggung jawab untuk melakukan sosialisasi melalui jalur kesenian. Penelitian demi penelitian terus dilakukan dan baru selesai pada akhir 1919 dengan diserahkannya laporan penelitian tentang influenza 1918 dari Flu selaku kepala laboratorium Dinas Kesehatan Hindia Belanda kepada W. Th. de Vogel selaku atasannya. Sebagai catatan Pada 1919 W. Th. de Vogel merupakan Kepala Dinas Kesehatan Rakyat (BGD).

Dari berbagai hasil masukan dan hasil penelitian, de Vogel menyimpulkan bahwa harus ada satu undang-undang untuk mengatur penyelesaian pandemi. Atas dasar ini Vogel mengusulkan rancangan undang-undang pandemi tahun 1919. Rancangan undang-undang yang disusun oleh Vogel baru disetujui oleh Gubernur Jenderal Johan Paul van Limburg Stirum pada 1920. Lamanya penyusunan undang-undang terjadi karena adanya konflik kepentingan, khususnya dalam bidang ekonomi. Salah satu yang melakukan protes keras terhadap undang-undang rancangan Vogel adalah direksi Koninklijk Paketvaart Maatschappij (KPM). Jajaran direksi KPM mengangap bahwa jika undang-undang rancangan Vogel disahkan, maka itu akan membatasi kinerja dan usaha KPM dan resikonya adalah kerugian besar pada perusahaan perkapalan ini (Langen, 1920).

Berbagai cara, meskipun lambat, telah dilakukan oleh pemerintah kolonial untuk menangani pandemi 1918. Dalam prosesnya, ada beberapa masalah yang semakin memperlambat penyelesaian pandemi. Pertama adalah kurangnya koordinasi antara pemerintah pusat dengan pemerintah daerah. Akibatnya para kepala daerah mengambil tindakan sendiri-sendiri yang tidak jarang berbeda antara satu dengan yang lain untuk menyelesaikan pandemi di daerahnya. Kedua adalah tingginya tingkat diskriminasi yang ada di Hindia-Belanda. Pada awal pandemi akses kesehatan hanya diberikan untuk orangorang Eropa dan Cina, sementara pribumi menjadi golongan terakhir yang ditangani. Ketiga kurang seriusnya pelaksanaan perbaikan kampung kumuh dan usaha vaksinasi yang dilakukan. Kondisi ini terjadi karena di satu sisi pemerintah kolonial ingin menyelesaikan pandemi, tetapi di sisi lain juga ingin mempertahankan stabilitas wilayah jajahan. Keempat adalah diskriminasi penanganan ketika dilakukan karantina wilayah. Pemerintah kolonial menerapkan karantina bertarif, yang menyebabkan orang miskin tidak mampu membayar sehingga ditempatkan di gudang yang tidak layak huni (Wibowo, 2009: 133).

Dengan berbagai masalah yang ada, kurva masyarakat Hindia Belanda pengidap Flu Spanyol mulai melandai dan akhirnya menurun pada awal tahun 1921. Tidak ada yang tahu secara pasti mengapa pengidap penyakit ini tiba-tiba menurun. Proses herd immunity menjadi kemungkinan yang paling masuk akal. Herd immunity terjadi melalui dua cara: : (1) vaksinasi terhadap $80 \%$ populasi dan (2) penyakitnya sendiri memberikan kekebalan alamiah setelah menginfeksi 80\% populasi (Metcalf, dkk., 2015: 753). Dalam kasus flu Spanyol, khususnya di Hindia-Belanda, cara kedua dinilai paling mungkin terjadi mengingat tidak ada catatan tentang program vaksinasi yang dilakukan oleh pemerintah kolonial Hindia-Belanda untuk menghentikan laju penyebaran penyakit flu Spanyol 


\section{Peran Dokter-Dokter Stovia dalam Penanganan Wabah Influenza Spanyol}

Wabah flu Spanyol yang melanda Hindia-Belanda membuat pemerintah kolonial kewalahan untuk mengatasinya. Segala sesuatu serba terbatas, mulai dari fasilitas kesehatan, tenaga kesehatan, obat-obatan, termasuk pengetahuan tentang penyakit. Oleh karena itu tidak heran jika flu Spanyol yang menyebar di Hindia Belanda pada awalnya tidak dianggap sebagai suatu penyakit yang serius oleh pemerintah kolonial (Cipta, 2020: 163). Ketika dibentuk komite untuk menyelidiki tentang pandemi yang sedang menyebar di Hindia tahun 1918, hasil temuannya juga tidak memberikan jawaban pasti tentang penyebab dari penyakit ini.

Pemerintah pusat di Batavia sebenarnya tidak bisa dikatakan tidak serius untuk menangani pandemi flu Spanyol, terutama setelah mendapatkan laporan tentang semakin banyaknya rakyat Hindia yang terjangkit penyakit baru ini. Persoalannya adalah praktik di lapangan seringkali tidak sejalan dengan aturan yang sudah dirumuskan. Mental diskriminatif yang dimiliki oleh penjajah Belanda masih dilakukan oleh banyak pegawai pemerintah di tingkat bawah. Tenaga medis kolonial lebih memprioritaskan mengobati orang-orang Eropa dan Cina karena dianggap lebih menjanjikan dari segi ekonomi. Sementara itu masyarakat pribumi yang umumnya miskin kesulitan untuk mendapatkan akses kesehatan (Wibowo, 2009: 60).

Perlakuan diskriminatif yang diterapkan oleh pemerintah kolonial membuat rakyat pribumi kecewa, sementara mereka tidak berdaya untuk melawan. Oleh karena itu para tenaga kesehatan pribumi yang telah mendapatkan pendidikan kesehatan dari STOVIA merasa peduli dan perlu memperjuangkan nasib saudara-saudara sebangsa yang sedang menderita. Selain karena faktor kemanusiaan, solidaritas sesama bangsa terjajah juga menjadi alasan para dokter lulusan STOVIA untuk ikut berjuang menyembuhkan rakyat yang sedang sakit akibat pandemi.

Perjuangan dilakukan dalam berbagai bidang, yang utama tentu dalam bidang kesehatan yaitu mengobati rakyat yang terjangkit flu Spanyol. Para dokter alumni STOVIA yang berjuang di bidang kesehatan tersebar di berbagai tempat. Sebagaian besar ditugaskan di rumah sakit, sebagian lagi ditugaskan di fasilitas-fasilitas kesehatan dalam skala kecil, dan sebagian kecil bertugas secara mandiri. Bahkan karena terbatasnya jumlah dokter, siswa STOVIA yang masih menempuh pendidikan juga dikirimkan ke berbagai daerah untuk membantu pemerintah mengatasi pandemi (Langen, dkk., 1920: 10). Dari sekian dokter alumni STOVIA yang berjuang untuk meredakan pandemi pandemi, nama Ismael dan Sutomo paling banyak disebut. Ismael bertugas di Rumah Sakit Kristen Mojowarno sementara Sutomo bertugas di Rumah Sakit Kristen Blora.

Di luar bidang pengobatan, para dokter juga aktif untuk melakukan penyuluhan kesehatan kepada masyarakat melalui kerja sama dengan tokoh setempat. Kegiatan yang bersifat promotif ini dilakukan sebagai bagian dari pelayanan utama seorang dokter, yaitu promotif, preventif, kuratif, dan rehabilitatif. Penyuluhan kesehatan dilakukan dengan memberikan edukasi kepada masyarakat tentang penyakit yang sedang mewabah dan cara 
menyikapinya. Contoh menarik terjadi di Mojowarno, dimana dokter dari Rumah Sakit Kristen Mojowarno seperti dr. Ismael dan dr. Sujalmo, tokoh agama, dan tokoh masyarakat saling bersinergi untuk melakukan penyuluhan kepada masyarakat (Steenbrink \& Aritonang, 2008: 635).

Selain dalam bidang kesehatan, perjuangan untuk mengatasi pandemi juga dilakukan melalui jalur parlemen atau Volksraad. Abdul Rivai adalah tokoh yang paling keras menyampaikan kritik kepada pemerintah kolonial melalui Volksraad. Abdul Rivai mengatakan dalam kritiknya bahwa Burgerlijk Geneeskundige Dienst (BGD) secara efektif telah mempersilahkan orang Jawa untuk mati karena wabah (Walker, 2014: 67). Lebih lanjut Rivai mengkritik bahwa rakyat Jawa dibiarkan mati seperti tikus. Kritik ini disampaikan Rivai karena rendahnya usaha dari pemerintah kolonial Belanda untuk mereduksi tingkat kematian di Jawa akibat wabah Flu Spanyol. Data yang diperoleh oleh Rivai menyebutkan bahwa kematian rakyat Hindia di Jawa melonjak sampai 900.000 orang selama empat bulan, terhitung sejak Agustus sampai November 1918.

Kritik demi kritik yang disampaikan oleh Rivai di Volksraad menyebabkan pemerintah kolonial terpaksa harus setuju dengan apa yang disampaikan oleh Rivai, bahwa mereka lambat dalam mengatasi pandemi. Pemerintah tidak bisa lagi menganggap remeh virus yang sedang mewabah di Hindia Belanda, karena data yang dikumpulkan oleh W. Th. de Vogel selaku Kepala BGD juga menunjukkan hasil yang sama, yaitu tingginya rakyat Hindia yang terjangkit influenza jenis baru dan tingginya angka kematian yang diakibatkan oleh virus ini. Meskipun terlambat dan penuh perdebatan, pemerintah akhirnya menindaklanjuti penyebaran wabah dengan menerbitkan Influenza Ordonantie pada 20 Oktober 1920 (Wibowo, 2009: 161).

Selanjutnya para tenaga medis aktif menulis di surat kabar untuk menyampaikan informasi kepada masyarakat tentang wabah Flu Spanyol dan mensosialisasikan protokol kesehatan yang harus dilakukan. Informasi yang disampaikan berupa pengetahuan mengenai jenis wabah yang sedang terjadi, gejala, dan penangannya (Khodafi, Septiani, \& Endi, 2020: 93). Seperti yang disampaikan oleh surat kabar Bataviaasch Nieuwsblad bertanggal 18 Juli 1918 yang menghimbau masyarakat untuk menjauhi orang batuk dan bersin, serta tindak berludah di tanah demi menghindari penyebaran penyakit (NN, De Epidemi, 1918).

Para pribumi alumni STOVIA juga banyak diberdayakan oleh pemerintah kolonial dalam berbagai kegiatan untuk mengatasi pandemi, khususnya sebagai mediator antara inspektur kolonial dengan rakyat Hindia. Hal ini dilakukan karena honor dokter pribumi lebih murah dibandingkan dokter Eropa, mengetahui bahasa dan kebiasaan rakyat Hindia, lebih tahan terhadap cuaca di Hindia Belana, dan lebih mampu bertahan di kawasan pedalaman. Meskipun sebatas sebagai mediator, karena dianggap belum layak menempati posisi wakil inspektur, tetapi pengaruhnya dapat dirasakan oleh masyarakat, yaitu pengetahuan tentang cara menghadapi penyakit yang selama ini tidak pernah mereka ketahui (Hesselink, 2011: 213-214). 
Perjuangan lain dilakukan oleh Sardjito yang masuk menjadi bagian komite yang dibentuk oleh pemerintah kolonial untuk menyelidiki tentang penyakit influenza yang sedang menyebar di Hindia Belanda. Komite ini terdiri dari CD de Langen (ketua), GOE Lignac (sekretaris), PC Flu, AA Hulshoff, J Huizinga, dan Mas Sardjito (anggota) (Doornum, 2020). Tugas dari komite ini adalah melakukan penyelidikan terhadap wabah influenza yang sedang menyebar, penyebab kemunculannya, gejala-gejalanya, tingkat penyebarannya, tingkat kematian yang ditimbulkan, pengalaman yang diperoleh selama epidemi ini, tindakan pencegahan, dan cara pengobatannya. Temuan dari Sardjito dan tim kemudian dijadikan landasan oleh pemerintah kolonial untuk merumuskan kebijakan yang akan dilakukan. Komite ini menganjurkan agar pemerintah mensosialisaskan kepada rakyat untuk melakukan program isolasi mandiri, meningkatkan kualitas dan kuantitas pelayanan rumah sakit, dan menggunakan obat-obat eksperimental untuk menekan laju penularan penyakit (Langen, dkk., 1920: 154).

\section{PENUTUP}

\section{A. Kesimpulan}

Kesimpulan dari penelitian ini adalah:

1. School tot Opleiding van Indische Artsen (STOVIA) awalnya bernama Dokter Djawa School yang didirikan atas usulan Willem Bosch pada 1849. Tujuan awal pendirian STOVIA adalah untuk memenuhi kebutuhan tenaga kesehatan di instansi pemerintah kolonial dan mendidik tenaga pembantu untuk mengatasi wabah cacar yang disertai demam tinggi di Jawa Tengah pada tahun 1846-1847. Menariknya, STOVIA pada awal berdirinya justru dianggap sebagai sekolah orang miskin karena program pendidikan gratis yang dimiliki. Dalam perkembangannya, STOVIA ternyata mampu menghasilkan alumni-alumni yang tidak saja mengabdi di bidang kesehatan, tetapi juga dalam bidang sosial, kebudayaan, dan politik. Lebih dari itu, embrio organisasi pergerakan nasional yaitu Boedi Oetomo juga didirikan oleh para alumni dari sekolah ini.

2. Flu Spanyol masuk ke Hindia-Belanda melalui interaksi dagang dengan pelaut-pelaut dari Hongkong pada awal tahun 1918. Segera setelah itu virus H1N1-1918 menyebar di Hindia Belanda. Cepatnya penyebaran diakibatkan oleh lambatnya sikap pemerintah kolonial untuk mengatasi virus ini. Diperkirakan 1,5 juta sampai 4,37 juta rakyat Hindia Belanda meninggal akibat pandemi Flu Spanyol. Tahun 1921 jumlah pasien Flu Spanyol menurun, sekaligus menjadi tanda bahwa wabah segera berakhir. Tidak diketahui penyebab berhentinya penyebaran virus H1N1-1918. Herd immunity menjadi alasan paling masuk akal.

3. Beberapa peran dokter pribumi alumni STOVIA dalam usaha menyelesaikan wabah Flu Spanyol adalah: (1) sosialisasi kepada masyarakat, baik secara langsung maupun melalui media cetak, (2) mengikuti program pemerintah kolonial untuk melakukan penelitian terkait wabah Flu Spanyol, (3) melakukan tindakan medis kepada pasien yang sakit, (4) 
menyampaikan aspirasi masyarakat melalui jalur legislatif (Volksraad), dan (5) menjadi mediator antara pemerintah kolonial dengan rakyat Hindia Belanda

\section{B. Saran}

Sejarah medis di Indonesia tergolong masih sedikit, terutama jika dibandingkan dengan sejarah politik, sosial, dan ekonomi. Maka penelitian tentang peran alumni STOVIA dalam penanganan wabah flu Spanyol di Hindia Belanda ini tergolong sebagai penelitian permulaan, karena belum banyak yang membahas peran para dokter Bumiputera dalam wabah tersebut. Oleh karena itu, diharapkan agar para peneliti yang memiliki konsentrasi dalam bidang sejarah kesehatan dan kedokteran agar dapat menyempurnakan penelitian ini, untuk semakin memperkaya khazanah sejarah medis di Indonesia.

\section{DAFTAR PUSTAKA}

“Influenza, Bahaja dari Influenza Dapet Dimenangin,” dalam Sin Po, 30 Oktober 1918.

“De Epidemi”, dalam Bataviaasch Nieuwsblad, Donderdag, 18 Juli 1918.

Bleeker, P. (1877). “Levensbericht P. Bleeker”, dalam Jaarboek. Amsterdam.

Boomgaard, P. (1993). "The Development of Colonial Health Care in Java: An Exploratory Introduction”. Bijdragen tot de Taal-, Land- en Volkenkunde, Vol. 149, No. 1.

Brown, C., "The Influenza Pandemic of 1918 in Indonesia, Chapter 11". Dalam: Owen, Norman G. (1987). Death and Disease in Southeast Asia. Singapore: Oxford University Press.

Chandra, S. (2013). "Mortality from the Influenza Pandemic of 1918-19 in Indonesia". Population Studies, Vol. 67, No. 2.

Cipta, S.E. (2020). "Upaya Penanganan Pemerintah Hindia Belanda Dalam Menghadapi Berbagai Wabah Penyakit DI Jawa 1911-1943”. Equilibrium, Vol. 8, No. 2.

Doornum, V., dkk. (2020). "Dutch Virology in the Tropics: From Colonial to International Virology", dalam Leeuwenhoek's Legatees and Beijerinck's Beneficiaries: A History of Medical Virology in The Netherlands. Amsterdam: Amsterdam University Press.

Hesselink, L. (2011). Healers on The Colonial Market. Leiden: Brill.

Khodafi, M., dkk. (2020). "Kilas-Balik Wabah di Indonesia: Mengurai Kembali Pandemi Covid-19 Melalui Peristiwa Flu Spanyol 1918-1920”. Suluk, Vol. 2.

Langen, D., dkk. (1920). "Mededeelingen van Den Burgerlijken Geneeskundigen Dienst in Nederlandsch-Indie", No. X.

Luwis, S. (2020). Epidemi Penyakit Pes di Malang, 1911-1916. Temanggung: Kendi Press.

Mansyur. (2020). "Pandemi Flu Spanyol di Banjarmasin, Karesidenan Borneo Bagian Selatan Dan Timur (1918-1920)". Yupa, Vol. 4, No. 1. 
Metcalf, C.J.E., dkk. (2015). "Understanding Herd Immunity”. Trends in Immunology, Vol. 36, Issue. 12.

Neelakantan, V. (2013). "Recollecting Jakarta's Social and Medical History," Bijdragen tot de Taal-, Land-en Volkenkunde, Vol. 169, no. 2-3.

Piret, J., Boivin, G. (2021). "Pandemics Throughout History". Frontiers in Microbiology, Vol. 11.

Poeze, H.A. (1989). "Early Indonesian Emancipation Abdul Rivai, Van Heutsz and The Bintang Hindia.” Bijdragen Tot De Taal-, Land-En Volkenkunde, Vol. 145, No. 1.

Pols, H. (2018). Nurturing Indonesia: Medicine and Decolonisation in The Dutch East Indies. Cambridge: Cambridge University Press.

Radiopoetro. (1976). "Sejarah Pendidikan Dokter di Indonesia”. Berkala Ilmu Kedokteran, Vol. VIII, No. 4.

Ravando. (2020). Perang Melawan Pandemi Influenza: Pandemi Flu Spanyol di Indonesia Masa Kolonial, 1918-1919. Jakarta: Kompas.

Salvadó, F.J.R. (2019). "Spain and The First World War: The Logic of Neutrality", War in History, Vol. 26, No. 1.

Steenbrink, K., dkk. (2008). "Christianity in Javanese Culture and Society," dalam A History of Christianity in Indonesia, Vol. 35. Leiden; Boston: Brill.

Taubenberger, J.K. (2006). "The Origin and Virulence of the 1918". Proceedings of the American Philosophical Society, Vol. 150, No. 1.

Walker, K. (2014). "The Influenza Pandemic of 1918 in Southeast Asia”, dalam Histories of Health in Southeast Asia: Perspectives on te Long Twentieth Century. Bloomington \& Indianapolis: Indiana University Press.

Wibowo, P., dkk. (2009). Yang Terlupakan: Sejarah Pandemi Influenza 1918 di Hindia Belanda. Depok: Kerjasama antara Departemen Sejarah Fakultas Ilmu Pengetahuan Budaya Universitas Indonesia, UNICEF Jakarta, dan Komnas FBPI.

www.covid19.who.int, diakses pada 26 Maret 2021.

Zwierstra, R.P. (2009). "Van vaccinateur tot academisch opgeleid arts. Over de geschiedenis van het medisch onderwijs in Nederlands-Indië". Tijdschrift voor Medisch Onderwijs, Vol. 28. 